\title{
Acute Toxicity of Insecticide Thiamethoxam to Crayfish (Astacus leptodactylus): Alterations in Oxidative Stress Markers, ATPases and Cholinesterase
}

\author{
Miraç Uçkun, ${ }^{1}$ Ertan Yoloğlu, ${ }^{2}$ Aysel Alkan Uçkun ${ }^{3 *}$ and Özden Barım Öz ${ }^{4}$ \\ ${ }^{1}$ Department of Food Engineering, Faculty of Engineering, Adıyaman University, Adıyaman, Turkey \\ ${ }^{2}$ Department of Mathematics and Science Education, Faculty of Education, Adryaman, Turkey \\ ${ }^{3}$ Department of Environmental Engineering, Faculty of Engineering, Adiyaman University, Adiyaman, Turkey \\ ${ }^{4}$ Department of Physiology, Faculty of Aquaculture, Firat University, Elazığ, Turkey \\ *Corresponding author: E-mail: ayseluckun@gmail.com \\ Phone: [+90] 4162233800/4539
}

Received: 06-03-2021

\begin{abstract}
Thiamethoxam (Thmx) is a globally used neonicotinoid pesticide contaminated in freshwater ecosystems with residues detected in fishery products. Astacus leptodactylus is a popular freshwater crustacean that is cultivated and exported in many countries. In this study, we investigated the acute toxic effects of Thmx on A. leptodactylus using various biomarkers (acetylcholinesterase, carboxylesterase, glutathione S-transferase, glutathione, superoxide dismutase, glutathione peroxidase, glutathione reductase, and adenosinetriphosphatases). The $96-\mathrm{h} \mathrm{LC}_{50}$ value of Thmx was calculated as 8.95 $\mathrm{mg}$ active ingredient $\mathrm{L}^{-1}$. As the dose of Thmx increased, oxidative stress was induced by the inhibition/activation of antioxidant enzymes, while the activities of acetylcholinesterase, carboxylesterase and adenosinetriphosphatases were inhibited. As a result, it can be said that Thmx has highly toxic effects on crayfish, therefore they are under threat in the areas where this pesticide is used.
\end{abstract}

Keywords: Acetylcholinesterase; Antioxidant enzymes; Crustacean; Insecticide; Metabolic enzymes; Toxicity

\section{Introduction}

Among the insecticides widely used in agriculture, it is necessary to focus on neonicotinoids, which are chemically similar to nicotine. ${ }^{1}$ Neonicotinoid insecticides have been the fastest growing insecticide class due to their safe use of biochemical properties, broad spectrum activities, and systemic distribution mechanism in plants.,3 Thiamethoxam (Thmx) 3-(2-chloro-1,3-thiazol-5-ylmethyl)5-methyl-1,3,5-oxadiazinan-4-ylidene (nitro) amine is one of the second generation neonicotinoid insecticides and is used against a wide target population of insects. ${ }^{4}$ Thmx is a potential pollutant that is mixed with surface and ground water due to its low absorption from the soil, high leakage capacity and high water solubility. ${ }^{5} \mathrm{Thmx}$, like other neonicotinoid insecticides, bind agonistically with high affinity to nicotinic acetylcholine receptors, which are target sites in insects. ${ }^{6}$ There is much informa- tion in the literature specific to the exposure profiles of neonicotinoids in aquatic ecosystems, but there is little information about second-generation neonicotinoids such as Thmx in published studies on the effects of neonicotinoids on non-target aquatic organisms. Knowing the effect of neonicotinoids on aquatic invertebrates provides important data for aquatic risk assessment. ${ }^{7}$ Although low-risk for some non-target organisms, Thmx is a potential pollutant for surface and groundwater due to its low absorption, low infiltration, high water solubility and resistance to biological treatment, therefore it poses a danger to aquatic organisms. ${ }^{89} \mathrm{Thmx}$ has been found to be generally around $0.001-225 \mathrm{ppb}$ in surface waters. ${ }^{10}$ The persistence in the soil (229 days) and high-water solubility $\left(4100 \mathrm{mg} \mathrm{L}^{-1}\right)$ of Thmx mean there is high potential to be transported into surface waters. ${ }^{11}$ The results of a comprehensive review of laboratory and semi-field microcosm studies show that aquatic invertebrates are highly susceptible to neonicoti- 
noids. ${ }^{12}$ However, the most studied of neonicotinoids in aquatic ecosystems is imidacloprid, the effects of a newer neonicotinoid, Thmx, on aquatic organisms have been less studied. ${ }^{13}$

Turkey's natural freshwater crayfish species, A. leptodactylus, one of the most popular species in Europe is due to the presence of a wide range of areas outside of Anatolia and economic importance. ${ }^{14}$ Crayfish are part of the ecological balance in their natural freshwater areas. Due to the important role they play in the processing of all kinds of organic materials, they are active on energy balances in the ecosystem, therefore they are seen as key species for still and fluvial habitats. ${ }^{15,16}$ Indicator species in aquatic ecosystems are considered to be a suitable way of demonstrating environmental quality. ${ }^{17}$ Not all organisms are suitable for use as an indicator. Crayfish are benthic, solitary, constantly in contact with objects, omnivorous, long-lived, slow-moving, narrow habitat, large enough to easily sample from different body tissues, and can accumulate pollutants increases its value as an indicator species. ${ }^{18}$

Many xenobiotics, including pesticides, can trigger the production of reactive oxygen species by various biochemical mechanisms, such as disruption of electron transport across the cell membrane, facilitation of the Fenton reaction, inactivation of antioxidant enzymes, and depletion of free radical scavengers. ${ }^{19}$ Antioxidant defense systems have been developed in organisms to scavenge these reactive oxygen species, and by evaluating the activation / inhibition level of these antioxidant systems, the oxidative damage caused by xenobiotics to the organism is estimated. ${ }^{20}$ The aim of this study was to investigate the acute toxic effects of Thmx on A. leptodactylus. For this, we tested the effect of different doses of Thmx on the enzymes responsible for ion homeostasis in the cell $\left(\mathrm{Na}^{+} / \mathrm{K}^{+}\right.$-ATPase, $\mathrm{Mg}^{2+}$-ATPase, $\mathrm{Ca}^{2+}$-ATPase), neurotoxicity biomarker acetylcholinesterase (AChE), antioxidant defense system parameters [superoxide dismutase (SOD), glutathione (GSH), glutathione peroxidase (GPx), glutathione reductase (GR)], an oxidative damage marker [malondialdehyde (MDA)], phase II biotransformation enzymes [glutathione S-transferase (GST), carboxylesterase $(\mathrm{CaE})]$ of aquatic invertebrate crayfish $A$. leptodactylus.

\section{Materials and Methods}

\section{1. Test Animals and Experimental Design}

Crayfish used in this study were obtained from the Crayfish Breeding Unit at the Firat University Fisheries Faculty, Elazığ, Turkey. During the study, glass aquariums with a capacity of 30 liters with tubular shelters were used. Studies were done at room temperature $\left(23 \pm 1{ }^{\circ} \mathrm{C}\right)$ and in natural daylight ( $12 \mathrm{~h}$ dark $/ 12 \mathrm{~h}$ light). Adequate ventilation was provided with the air pump. Rested tap water was placed in the aquariums. Before applying the pesticide, the crayfish were adapted to the laboratory environment for 15 days. Matured crayfish were used regardless of their gender. In order to achieve standardization, crayfish weighing around $20 \pm 5 \mathrm{~g}$ were preferred. Crayfish were not given food during the applications. The pesticide sold under the trade name Actara 25 WG was obtained from Syngenta. The Active Ingredient (AI) of Thmx is $240 \mathrm{~g} \mathrm{~L}^{-1}$. Water prepared according to ASTM standards was used in the study. ${ }^{21}$ Stock solution of $5000 \mathrm{mg} \mathrm{L}^{-1}$ was prepared freshly by dissolving Thmx in tap water. Test waters containing Thmx solution were left in the containers with static renewal every 24 hours and the $\mathrm{pH}$ values of these waters were recorded daily. A total of five groups were formed, four of which were the pesticide-treated groups and one was the non-pesticide-applied group (control). Four crayfish were placed in each aquarium and the study was done in three replicates, so fifteen aquariums and sixty animals were used in total.

\section{2. Determination of $\mathrm{LC}_{50}$ Values and Application Concentrations of Thiamethoxam}

Dose ranges of $0.50-400 \mathrm{mg} \mathrm{L}^{-1}$ of the commercial stock solution were used to determine the $96-\mathrm{h} \mathrm{LC}_{50}$ value of Thmx. Among live animals, those who were immobilized over time and showed signs of death were considered dead. ${ }^{22}$ The number of dead animals was recorded at $24,48,72$ and 96 hours and accordingly $96 \mathrm{~h}-\mathrm{LC}_{50}$ was determined as $8.95 \mathrm{mg} \mathrm{AI} \mathrm{L}^{-1}$ using SPSS 24 probit. This determined $\mathrm{LC}_{50}$ dose and its three sub-doses of Thmx $\left(\mathrm{LC}_{50} / 2, \mathrm{LC}_{50} / 4, \mathrm{LC}_{50} / 8\right)$ were administered to the crayfish. No Thmx application was applied to the control group. The experiment was repeated three times for each group of four animals $(\mathrm{N}=12)$. After applying solutions containing Thmx at its own concentration to each group for 96 hours, the animals were sacrificed and the hepatopancreas, muscle and gill tissues were removed and stored at $-80^{\circ} \mathrm{C}$ until analyzed. An ice bath was used for anesthesia of the animals, and the abdominal areas of the animals between the thorax and tail were dissected. ${ }^{23}$

\section{3. Biochemical Assays}

Analysis of biochemical markers was performed in tissues of surviving animals after a $96-\mathrm{h}$ acute toxicity test. The numbers of animals by groups are as follows: Control: 12, $\mathrm{LC}_{50} / 8: 12, \mathrm{LC}_{50} / 4: 12, \mathrm{LC}_{50} / 2: 9, \mathrm{LC}_{50}: 8$. Homogenisation of the tissues was carried out in homogenization buffer $(0.1 \mathrm{M}, \mathrm{pH} 7.4$ in potassium phosphate buffer; 0.15 $\mathrm{M} \mathrm{KCl}, 1 \mathrm{mM}$ EDTA, $1 \mathrm{mM}$ DTT) and on ice using a polytron homogenizer (Heidolph RZ 2021 Germany). The homogenates were centrifuged at $16,000 \times \mathrm{g}$ for $20 \mathrm{~min}$ at $4^{\circ} \mathrm{C}$ (Hettich $\left.460 \mathrm{R}\right)$. Total protein and all enzyme readings were done in triplicate on a microplate reader (Thermo Varioscan Flash 2000). The total protein level was meas- 
ured according to Bradford method (1976). ${ }^{24}$ The protein levels of the samples were determined using the standard curve constructed from measurements of the following bovine serum albumin standard solutions. In hepatopancreas tissue, GST, GR, AChE, CarE, GPx, SOD, GSH and MDA analyses were performed. ATPases analyses were done in gill and muscle tissues. All enzyme activities were expressed as specific activity $\left(\mathrm{nmol} \mathrm{min}{ }^{-1} \mathrm{mg}\right.$ protein $\left.{ }^{-1}\right)$.

\section{3. 1. Cellular Redox Status}

The GST activity was determined by a spectrophotometric method according to protocol described by Habig et al. (1974) $)^{25}$ using CDNB as substrate. The change in absorbance was measured at $344 \mathrm{~nm}$ for $2 \mathrm{~min}$. The GR activity was detected according to Cribb et al., (1989) ${ }^{26}$ by microplate assay with modifications. The reaction was initiated by the addition of GSSG into the reaction solution. Due to formation of GSH from GSSG, the decrease in the amount of DTNB was monitored at $405 \mathrm{~nm}$ for $3 \mathrm{~min}$. The CarE activity was determined according to a modified procedure of Santhoshkumar and Shivanandappa (1999) ${ }^{27}$ for a microplate reader. The reaction was initiated by the addition of PNPA as substrate to the reaction solution. The liberated $p$-nitrophenol was monitored at $405 \mathrm{~nm}$ for 2 min. In the determination of GPx activity, the method developed by Bell et al. (1985), ${ }^{28}$ Based on using hydrogen peroxide $\left(\mathrm{H}_{2} \mathrm{O}_{2}\right)$ as substrate and sodium azide $\left(\mathrm{NaN}_{3}\right)$ as catalase inhibitor, was used. The specific activity value of the enzyme was calculated based on the change in absorbance at $340 \mathrm{~nm}$ based on the oxidation of NADPH in a microplate reader. Superoxide dismutase (SOD) activity was determined by the method (Sun et al., 1988) ${ }^{29}$ based on the production of superoxide radicals by interacting xanthine with xanthine oxidase. The absorbance value was measured according to the color change created by the interaction of superoxide radicals with nitrobluetetrazolium. The reduced GSH level was determined according to Moron et al. (1979) ${ }^{30}$ with some modifications adapted to microplate reader system. The absorbance was read at 412 $\mathrm{nm}$ against the GSH standard curve. GSH level of samples was expressed as nmol GSH mg ${ }^{-1}$ protein. The MDA concentration was measured based on thiobarbituric acid reactive substance assay as described by Placer et al. $(1966)^{31}$ with some modifications. The absorbance was read at 532 $\mathrm{nm}$. MDA contents were determined using malondialdehyde bis (diethyl acetal) as a standard. The MDA concentration was expressed as nmol MDA mg ${ }^{-1}$ protein.

\section{3. 2. Neurotoxicity (AChE)}

The AChE activity was determined following the Ellman and Andres (1961) ${ }^{32}$ method using ACTI as a substrate, modified for the microplate reader by Ozmen et al. (1998). ${ }^{33}$ Enzyme activity was monitored at $412 \mathrm{~nm}$ for 1 $\min$.

\subsection{Ion Transport}

The methods of Atli and Canll (2011) ${ }^{34}$ were used to determine ATPase activities $\left(\mathrm{Na}^{+} / \mathrm{K}^{+}\right.$-ATPase, $\mathrm{Mg}^{2+}$-ATPase, $\mathrm{Ca}^{2+}$-ATPase ) in gill and muscle. Analyzes were performed in a microplate reader in triplicate. $5 \mu \mathrm{L}$ of sample and $60 \mu \mathrm{L}$ of incubation medium consisting of $1 \mathrm{mM}$ ouabain, $40 \mathrm{mM}$ Tris- $\mathrm{HCl}, 4 \mathrm{mM} \mathrm{MgCl} 2,20 \mathrm{mM} \mathrm{KCl}$ and $100 \mathrm{mM} \mathrm{NaCl}$ were pipetted into each microplate well and incubated at $37^{\circ} \mathrm{C}$ for 5 minutes. $10 \mu \mathrm{L}$ of $3 \mathrm{mM}$ ATP was added to the top of the mixture in these wells and incubated at $37^{\circ} \mathrm{C}$ for 30 minutes, so the reaction was initiated. After incubation, $35 \mu \mathrm{L}$ of cold distilled water $\left(+4^{\circ} \mathrm{C}\right)$ was added to these wells to stop the reaction. The value of the inorganic phosphate $(\mathrm{Pi})$ released from ATP at the end of the reaction was calculated by measuring the absorbance at $390 \mathrm{~nm}$ of the yellow compound formed by the main reagent consisting of polyoxyethylene 10 lauryl ether and ammonium molybdate (Atkinson et al. 1973). ${ }^{35} 190 \mu \mathrm{L}$ of main reagent was added to microplate wells containing $60 \mu \mathrm{L}$ of incubation medium, $5 \mu \mathrm{L}$ of supernatant and $35 \mu \mathrm{L}$ of cold distilled water, and after incubating at room temperature for 10 minutes, absorbance values were measured at $390 \mathrm{~nm}$. The results were evaluated based on the standard curve obtained using different concentrations of $\mathrm{KH}_{2} \mathrm{PO}_{4}$ solution. Enzyme activities were expressed as specific activity $\left(\mu \mathrm{mol} \mathrm{P}_{\mathrm{i}} \mathrm{min}^{-1}\right.$ mg protein ${ }^{-1}$ ). $\mathrm{Na}^{+} / \mathrm{K}^{+}$ATPase activity was calculated by subtracting the $\mathrm{Mg}^{2+}$ ATPase (containing Ouabain) activity from the total ATPase (without Ouabain) activity. The $\mathrm{Mg}^{2+}$ ATPase activity arises from the inhibition of Ouabain's activity by binding to $\mathrm{Na}^{+} / \mathrm{K}^{+}$ATPase. $\mathrm{Ca}^{2+}$ ATPase activity was calculated by subtracting the enzyme activity measured in the absence of enzyme activity in the presence of $\mathrm{CaCl}_{2}$.

\section{4. LC-MS/MS Analysis of Thiamethoxam in the Test Water}

The actual Thmx concentrations in the test waters were determined using a liquid chromotgraphy tandem mass spectrometry (LC-MS/MS) in Adiyaman University Central Research Laboratory. The retention time of Thmx was aproximately $3.84 \mathrm{~min}$. The calibration curve constructed from the standards for the calculation of Thmx concentrations was in the range of $1-100 \mu \mathrm{g} \mathrm{L}^{-1}$. The limits of detection, quantification, and coefficient of determination $\left(\mathrm{r}^{2}\right)$ were determined as $0.07 \mu \mathrm{g} \mathrm{L}^{-1}, 0.32 \mu \mathrm{g} \mathrm{L}-1$, and 0.999 , respectively. Thmx was detected through the transitions $292.1 \rightarrow 211.0$ mass-to-charge ratio $(\mathrm{m} / \mathrm{z}$ ) (collision energy (CE); $-12 \mathrm{~V}$ ) and $292.1 \rightarrow 181.0 \mathrm{~m} / z$, CE; $-24 \mathrm{~V}$. The Thmx standard was purchased from Dr. Ehrenstorfer $\mathrm{GmbH}$ with $99.8 \%$ purity. Each water sample was analyzed in triplicate.

\section{5. Data Analyses}

In the statistical analysis of the data, computer software package SPSS 22 was used. Data normality was evaluated using Shapiro-Wilk test $(p<0.05)$. Kruskal Wallis 
test was used to determine the comparison of data between groups. Mann Whitney U test was used to determine whether there was a significant difference within the groups. The statistical significance level was based on $p<0.05$.

The integrated biomarker response (IBR) was used to incorporate all the biochemical marker reactions assessed into a single overall stress index to determine the risk potential of thiamethoxam. The IBR indexes were calculated according to the method defined by Arzate-Cárdenas and Martínez-Jerónimo (2012). ${ }^{36}$ The IBR index was calculated based on the mean and standard deviation for each biomarker. The average value for each response was standardized separately using the formula $\mathrm{Y}=(\mathrm{Xm}) / \mathrm{SD}$; where $\mathrm{Y}$ is the standardized value, $\mathrm{X}$ is the average value, and $\mathrm{m}$ is the average of the biochemical markers. Depending on the biochemical responses, $Z$ values were calculated as $Z=Y$ (inhibition) or $Z=-Y$ (activation). Score (S) was evaluated with the formula $S=|\min |+Z$; where $|\mathrm{min}|$ is the absolute value of the minimum of all biochemical markers. The scores were utilized were $[(\mathrm{S} 1 \times \mathrm{S} 2) / 2+(\mathrm{S} 2 \times \mathrm{S} 3) / 2+\ldots(\mathrm{Sn}-1 \times$ $\mathrm{Sn}) / 2$ ] to give a normalized IBR, and estimated values were divided by the number of biochemical markers calculated.

\section{Results and Discussion}

\section{1. The Actual Thiamethoxam Concentrations in the Test Waters}

Data on the actual concentrations of Thmx in solutions applied to crayfish as determined by LCMSMS are shown in Table 1 . A difference of approximately $15 \%, 12 \%$, $10 \%$ and $11 \%$ was found between the nominal and actual concentrations, respectively. These differences may be because Thmx is not sufficiently soluble in water due to surfactants, solvents, and preservatives found in this commercial form (Korkmaz et al. 2018). ${ }^{37}$

Table 1. Concentrations measured by LCMSMS in test waters (Actual concentrations expressed as mean \pm standart error)

\begin{tabular}{lcccc}
\hline Nominal Dose & N & Mean & & SE \\
\hline 1.12 & 3 & 0.95 & \pm & 0.03 \\
2.24 & 3 & 1.97 & \pm & 0.04 \\
4.48 & 3 & 4.01 & \pm & 0.06 \\
8.95 & 3 & 7.98 & \pm & 0.04 \\
\hline
\end{tabular}

\section{2. Acute Toxicity Assay}

In our search, and to the best of our knowledge, no peerreviewed studies examining Thmx toxicity to A. leptodactylus have been published. In our study, the 96-hour acute lethal concentration value $\left(96 \mathrm{~h}-\mathrm{LC}_{50}\right.$ ) of Thmx for A. leptodactylus was determined as $8.95 \mathrm{mg} \mathrm{AI} \mathrm{L}^{-1}$. The 96 h LC ${ }_{50}$ value for crayfish, Procambarus clarkii was determined as $0.967 \mathrm{mg} \mathrm{AI} \mathrm{L}^{-1}$ by Barbee and Stout (2009) ${ }^{38}$ and $10 \mathrm{mg} \mathrm{AI} \mathrm{L}^{-1}$ by Maloney et al. $(2018)^{39}$ in two separate studies. In a study, $48-\mathrm{h} \mathrm{LC}_{50}$ value of $\mathrm{Thmx}$ for water louse Asellus aquaticus was found as $2.3 \mathrm{mg} \mathrm{L}^{-1} \cdot{ }^{39}$ For crustacean Gammarus kischineffensis, the 96-h LC $\mathrm{LC}_{50}$ value of Thmx determined as $8.985 \mathrm{mg} \mathrm{L}^{-1}$ and $3.751 \mathrm{mg}$ $\mathrm{L}^{-1}{ }^{40,41}$ The reason that these acute $\mathrm{LC}_{50}$ values of $\mathrm{Thmx}$ determined for crustaceans differ from each other may be due to the differences in the experimental conditions and the parameters such as application period, physiological status, life stage, age and body weight of the animals used in the experiment. ${ }^{42}$

\section{3. Mortality Rates of Crayfish Determined During 96-h of Study}

The mortality rates of crayfish exposed to Thmx at different concentrations for 24, 48, 72 and 96-h are shown in Table 2. No death was observed at any Thmx concentration at $24^{\text {th }}$ hour. At $48^{\text {th }}$ hour, only 1 death was observed for each of the $\mathrm{LC}_{50} / 2$ and $\mathrm{LC}_{50}$ doses. At $72^{\text {th }}$ hour, 1 animal died at the $\mathrm{LC}_{50} / 2$ dose and 2 animals died at the $\mathrm{LC}_{50}$ dose. At $96^{\text {th }}$ hour, 1 animal died at both the $\mathrm{LC}_{50} / 2$ and $\mathrm{LC}_{50}$ doses. Mortality rates were $25 \%$ and $33 \%$ at the $\mathrm{LC}_{50} / 2$ and $\mathrm{LC}_{50}$ doses, respectively and the difference between these groups from control was statistically significant $(\mathrm{p}<0.05)$.

Comparison of mortality rates were made by Dunnett's t-test. Results showed statistical importance compared with control $\left({ }^{*}: \mathrm{p}<0.05\right) . \mathrm{LC}_{50} / 8: 1.12 \mathrm{mg} \mathrm{AI} \mathrm{L} \mathrm{L}^{-1}$. $\mathrm{LC}_{50} / 4: 2.24 \mathrm{mg} \mathrm{AI} \mathrm{L}^{-1}$. LC $\mathrm{L}_{50} / 2: 4.48 \mathrm{mg} \mathrm{AI} \mathrm{L}{ }^{-1}$. $\mathrm{LC}_{50}: 8.95$ $\mathrm{mg} \mathrm{AI} \mathrm{L}{ }^{-1}$. N: The number of the animals used.

\section{4. Biochemical Responses}

The data of the biomarkers evaluated in the hepatopancreas are given in Table 3, those in the gill in Table 4, and those in the muscle in Table 5.

Table 2. The mortality of crayfish exposed to Thmx at different concentrations for $24,48,72$ and $96-\mathrm{h}$.

\begin{tabular}{|c|c|c|c|c|c|c|c|}
\hline $\begin{array}{l}\text { Concentration } \\
\left(\mathrm{mg} \mathrm{AI} \mathrm{L}^{-1}\right)\end{array}$ & $\mathbf{N}$ & $24 \mathrm{~h}$ & $48 \mathrm{~h}$ & $72 \mathrm{~h}$ & $\begin{array}{l}\text { Mortality } \\
\quad 96 \mathrm{~h}\end{array}$ & Total death & Mortality rate (\%) \\
\hline Control & 12 & 0 & 0 & 0 & 0 & 0 & 0 \\
\hline $\mathrm{LC}_{50} / 8$ & 12 & 0 & 0 & 0 & 0 & 0 & 0 \\
\hline $\mathrm{LC}_{50} / 4$ & 12 & 0 & 0 & 0 & 0 & 0 & 0 \\
\hline $\mathrm{LC}_{50} / 2$ & 12 & 0 & 1 & 1 & 1 & 3 & $25^{\star}$ \\
\hline $\mathrm{LC}_{50}$ & 12 & 0 & 1 & 2 & 1 & 4 & $33^{*}$ \\
\hline
\end{tabular}




\section{4. 1. Cellular Redox Status}

In GST activity, there were significant increases in all Thmx concentrations, not dependent on Thmx concentration increase compared to the control group. The highest increase in GST activity was seen in the group in which the $\mathrm{LC}_{50} / 4$ dose was applied. The GST activity value at the $\mathrm{LC}_{50}$ concentration was close to that of the $\mathrm{LC}_{50} / 4$ concentration. Contrary to uor study, Han et al. (2016) ${ }^{43}$ observed a significant increase in GST activity in the liver of zebra fish treated with azoxystrobin for 4 weeks and attributed this increase to the free radical scavenging effect of GST. Husak et al. (2017) ${ }^{44}$ found that when they applied penconazole to goldfish, the GST activity in their livers was significantly higher than the control group. Similarly, Korkmaz et al. $(2018)^{37}$ observed GST was induced by phosalone-based (PBP) and cypermethrin-based (CBP) pesticides in zebrafish (Danio rerio) after 96 h exposure. Liu et al. $(2015)^{45}$ suggested that when azoxystrobin was applied to green algae Chlorella vulgaris, GSH level decreased and GST activity increased due to excessive ROS production, thus scavenging free radicals. GST catalyzes the conjugation of xenobiotics with GSH, allowing them to be removed from the organism ${ }^{46}$ thus, GST induction is used as a biomarker of cellular damage caused by xenobiotics. ${ }^{47}$ There are many studies in the literature revealing that GST activity increases in aquatic organisms treated with pesticide. ${ }^{48-52}$

GR activity decreased significantly in the Thmx applied groups compared to the control. The greatest increase in inhibition was seen at the $\mathrm{LC}_{50}$ dose, with a rate of approximately $84 \%$ compared to the control. Although all inhibitions were statistically significant, the least inhibition was seen at $\mathrm{LC}_{50} / 8$ dose with $76 \%$ difference from the control. GR is an enzyme that indirectly acts as an antioxidant by converting oxidized glutathione (GSSG) formed during reactions catalyzed by glutathione peroxidase (GPx) and glutathione S-transferase (GST) into reduced glutathione (GSH). ${ }^{53}$ In this study, observation of significant decreases in GR activity in all groups may be due to extracellular transport of GSSG rather than GSH to inhibit the cytotoxic effects of Thmx. ${ }^{54}$

CarE activity was significantly inhibited in all Thmx concentrations compared to the control. At the highest Thmx concentration $\left(\mathrm{LC}_{50}\right)$ the greatest inhibition (approximately $55 \%$ increase over control) was observed. CarEs are members of the esterase family that catalyze the hydrolysis of substrates such as carboxylic esters, thioesters, amides and carbamates, and various xenobiotics. ${ }^{55}$ CarEs are involved in important physiological processes such as lipid metabolism, ${ }^{56}$ pro-drug activation, ${ }^{57}$ pesticide metabolism, ${ }^{58}$ and hydrolysis of phthalates. ${ }^{59}$ In agreement with our results, Denton et al. (2003) ${ }^{60}$ reported that CarE activity was inhibited by $50 \%$ in fathead minnows compared to the unexposed group due to diazinon exposure. Wheelock et al. (2005) ${ }^{61}$ observed that after applying chlorpyrifos to Chinook salmon (Oncorhynchus tshawytscha) for 96 hour, CarE activity decreased signif- icantly compared to control. Uçkun and Öz (2020a),,$^{51}$ who first demonstrated that CarE was inhibited as a result of acute application ( $96 \mathrm{~h}$ ) of pesticide penconazole to crayfish, suggested that CarE is a sensitive biomarker of pesticide toxicity in crayfish hepatopancreas. In our study, data on CarE inhibition due to Thmx administration also support this view.

In GPx activity, there were significant increases in all Thmx concentrations. These increases in GPx activity were not dependent on dose increase. The greatest increase was seen at the $\mathrm{LC}_{50} / 8$ dose, approximately $44 \%$ difference from the control. The main function of GPx is to reduce the lipid hydroperoxides formed in the cell due to xenobiotic exposure to their end product alcohols and to reduce free hydrogen peroxide. ${ }^{62,63}$ Inhibition in the GPx enzyme may reflect the failure of the antioxidant system to prevent the destructive effect of the pesticide, ${ }^{64}$ or it may be related to the direct effect of reactive oxygen species formed in cells on the synthesis of this enzyme. ${ }^{65}$ From this perspective, the GPx increase observed in this study may reflect the protective role of GPx against the oxidative damage induced by Thmx in the cell. In parallel with our findings, Blahova et al. ${ }^{66}$ found that when they subchronically applied atrazine to zebrafish, GPx activity was significantly increased.

There was a decrease in SOD activity at the $\mathrm{LC}_{50} / 8$ dose, and an increase in the other doses compared to the control depending on the dose. Only the increase in the $\mathrm{LC}_{50}$ administration dose was statistically significant from the control $(p<0.05)$. SOD is an important antioxidant enzyme that catalyzes the conversion of superoxide radicals to $\mathrm{H}_{2} \mathrm{O}_{2}$ and $\mathrm{O}_{2}{ }^{-}$in organisms and forms the first defense against free oxygen radicals formed in cells. ${ }^{67}$ When an organism is exposed to a xenobiotic, a decrease in the antioxidant system may be followed by an increase, which may reflect that the organism is adapting. ${ }^{68,69}$ The increase in SOD activity at high Thmx concentrations indicates that SOD scavenges the overproduction of superoxide ions under the oxidative stress created by Thmx. Many studies have shown that SOD activity is increased in organisms exposed to pesticides. ${ }^{66,70,71}$

GSH level decreased significantly in all groups treated with Thmx compared to control. The greatest reduction was seen at the $\mathrm{LC}_{50}$ dose, with a rate of $45 \%$. GSH is an essential endogenous tripeptide, which prevents the cell from oxidative injury. GSH acts as a cofactor for GST, ${ }^{72}$ which is responsible for detoxification of xenobiotics, so an increase or decrease in GSH level can be an important indicator of the detoxification ability of the organism. ${ }^{73}$ Our findings are in line with many studies in the literature that GSH level decreased as a result of pesticide application to aquatic organisms. ${ }^{74-78}$ A decrease in GSH may mean that the antioxidant defense system is activated against the oxidative damage caused by ROS in the cell, as this reduction is an indication that GSH is spent converting to oxidized glutathione or regenerating GSH. ${ }^{79}$ Also, a 
Table 3. Biochemical responses of $96-\mathrm{h}$ Thmx exposure in hepatopancreas. Total protein amount expressed as $\mathrm{mg} \mathrm{ml}^{-1}$, and enzyme activities expressed as nmol $\mathrm{min}^{-1} \mathrm{mg}_{\text {protein }}{ }^{-1} \pm$ mean standard error. GSH and MDA levels expressed as nmol GSH mg protein $^{-1} \pm$ mean standard error and nmol MDA mg protein ${ }^{-1} \pm$ mean standard error, respectively.

\begin{tabular}{|c|c|c|c|c|c|c|c|c|c|c|}
\hline Dose & & $\begin{array}{c}\text { Total } \\
\text { Protein }\end{array}$ & GST & GR & AChE & CarE & GPx & SOD & GSH & MDA \\
\hline Control & 12 & 5.74 & $160.86 \pm 7.03$ & $36.91 \pm 1.70$ & $6.42 \pm 0.36$ & $5442.60 \pm 278.80$ & $8.01 \pm 0.33$ & $4.47 \pm 0.21$ & $0.20 \pm 0.02$ & $3.00 \pm 0.17$ \\
\hline $\mathrm{LC}_{50} / 8$ & 12 & 9.87 & $282.77 \pm 3.72^{*}$ & $8.98 \pm 0.20^{*}$ & $2.91 \pm 0.10^{*}$ & $2884.40 \pm 39.03$ * & $14.24 \pm 0.51^{*}$ & $4.04 \pm 0.11$ & $0.13 \pm 0.01^{*}$ & $3.07 \pm 0.04$ \\
\hline $\mathrm{LC}_{50} / 4$ & 12 & 7.62 & $395.32 \pm 9.74^{*}$ & $8.49 \pm 0.27^{*}$ & $3.23 \pm 0.11^{*}$ & $2968.20 \pm 88.25^{*}$ & $14.23 \pm 0.51^{*}$ & $4.61 \pm 0.15$ & $0.14 \pm 0.03^{*}$ & $4.23 \pm 0.21^{*}$ \\
\hline $\mathrm{LC}_{50} / 2$ & 9 & 8.72 & $277.38 \pm 10.3^{*}$ & $8.84 \pm 0.31^{*}$ & $1.50 \pm 0.10^{*}$ & $3075.10 \pm 110.50^{*}$ & $11.22 \pm 0.17^{*}$ & $6.77 \pm 0.22$ & $0.14 \pm 0.01^{*}$ & $4.58 \pm 0.12^{*}$ \\
\hline $\mathrm{LC}_{50}$ & 8 & 11.43 & $385.33 \pm 5.01^{*}$ & $6.09 \pm 0.33^{*}$ & $1.84 \pm 0.07^{*}$ & $2455.50 \pm 61.82$ * & $13.48 \pm 1.13^{*}$ & $7.92 \pm 0.28^{*}$ & $0.11 \pm 0.01^{*}$ & $5.29 \pm 0.30^{*}$ \\
\hline
\end{tabular}

$\mathrm{N}$ : Number of animals that survived after the $96-\mathrm{h}$ acute toxicity test.

${ }^{*}: p<0.05$ showed statistical importance compared with control group.

decrease in GSH level indicates a disrupt in phase II biotransformation, which increases the risk of oxidative stress due to decreased cell protection activity. ${ }^{80}$

There was an increase in the MDA level at all Thmx concentrations and these increases were in a dose-dependent fashion. Differences in all concentrations were statistically significant except for the $\mathrm{LC}_{50} / 8$ concentration. The highest increase in MDA level was at the $\mathrm{LC}_{50}$ concentration, approximately $43 \%$ compared to the control. Lipid peroxidation is the first indicator of cell membrane damage caused by exposure of organisms to pesticides, metals and various xenobiotics. ${ }^{81}$ The reason for the high level of MDA in our study may be the peroxidation of unsaturated fatty acids in the cell membranes, as Thmx exposure causes oxidative damage in the cell and increases ROS production. It has been reported that the level of MDA increased significantly in various aquatic organisms exposed to different pesticides compared to the groups not treated with pesticides. ${ }^{44,66,78,82,83,84}$

\section{4. 2. Neurotoxicity (AChE)}

There was a significant decrease in AChE activity in the Thmx applied groups compared to the control. The reductions in all Thmx concentrations relative to control were not dose dependent. The highest AChE inhibition was observed in the $\mathrm{LC}_{50} / 2$ group with an approximately $77 \%$ difference from the control. The inhibition in the $\mathrm{LC}_{50}$ application was approximately $71 \%$ compared to the control. When AChE is inhibited by xenobiotics, acetylcholine accumulates in the synaptic space and the receptors are highly stimulated. Activation of muscarinic ACh receptors is relatively slow (milliseconds to seconds) and, depending on the subtypes present, they directly alter cellular homeostasis. Unlike muscarinic receptors, the nicotinic receptors are inactivated due to sustained increase in ACh concentrations, which ultimately results in paralysis. Therefore, $\mathrm{AChE}$ is used as a biomarker of pesticides that target it directly or indirectly by altering the cholinergic neurotransmission. ${ }^{85}$ In our study, significant AChE inhibition due to Thmx administration indicates that Thmx has neurotoxic effects in crayfish at the doses applied. Similar to our findings, AChE inhibition was observed after 96 hours of Thmx application to the midge Chironomus riparius. ${ }^{86}$ Many researches reported that $\mathrm{AChE}$ is inhibited by neonicotinoid pesticides in various aquatic organisms. ${ }^{87-89}$

\section{4. 3. Ion Transport}

ATPases are responsible for ion homeostasis in cell membranes, play a central role in the physiological functions of the cell by providing energy conversion in chemical reactions, ${ }^{90}$ so they are considered a good indicator in toxicological studies. In our study, significant inhibitions of all ATPases $\left(\mathrm{Na}^{+} \mathrm{K}^{+}\right.$ATPase, $\mathrm{Mg}^{2+}$ ATPase, $\mathrm{Ca}^{2+}$ ATPase $)$ were noticed in $\mathrm{Thmx}$ treated groups in both gill and muscle compared to control (Table 3 and Table 4).

$\mathrm{Na}^{+} \mathrm{K}^{+}$ATPase was inhibited at the highest $\mathrm{Thmx}$ concentration $\left(\mathrm{LC}_{50}\right)$ in both gill and muscle. In gill tissue, inhibitions at all Thmx doses were significant $(\mathrm{p}<0.05)$. $\mathrm{Na}^{+} \mathrm{K}^{+}$ATPase inhibition rates in the gill were $25 \%, 49 \%$, $50 \%$ and $71 \%$, respectively, based on the applied Thmx concentrations. In muscle tissue, all $\mathrm{Na}^{+} \mathrm{K}^{+}$ATPase inhibitions were statistically significant except for $\mathrm{LC}_{50} / 8$ $(\mathrm{p}<0.05) . \mathrm{Na}^{+} \mathrm{K}^{+}$ATPase inhibition rates relative to control in muscle were $6 \%, 17 \%, 38 \%$ and $42 \%$, respectively. $\mathrm{Na}^{+} \mathrm{K}^{+}$ATPase has a vital function in maintaining the cell membrane potential difference by keeping $\mathrm{Na}^{+}$outside the cell and $\mathrm{K}^{+}$inside the cell. ${ }^{91}$ Inhibitions in $\mathrm{Na}^{+} \mathrm{K}^{+} \mathrm{AT}$ Pase activity indicates the destruction of cellular ion regulation in the tissues of fish. ${ }^{92}$ The researcher reported that this degradation may also be due to the effect of pesticide on the passive movement of ions, namely its permeability properties. Cirrhinus mrigala, which is exposed to the lethal and subletal effects of deltamethrin, has been found to decrease $\mathrm{Na}^{+} \mathrm{K}^{+}$ATPase activity in gill, liver and muscle tissue. ${ }^{93}$ It has been determined that the gill tissue $\mathrm{Na}^{+} \mathrm{K}^{+}$ATPase activity of Cyprinus carpio, which is exposed to cypermethrin sub-lethal effect for different periods, shows a decrease depending on the time. ${ }^{94}$ Similar observations were reported by Begum (2011) ${ }^{92}$ in the fish C. batrachus exposed to carbofuran. In a study conducted by Temiz et al. (2018), ${ }^{95}$ it was determined that under the effect of chlorantraniliprole (CHL), the decrease in 
Table 4. Biochemical responses of 96- $\mathrm{h}$ Thmx exposure in gill. Total protein amount expresses as $\mathrm{mg} \mathrm{ml}^{-1}$, and enzyme activities expressed as $\mu \mathrm{mol} \mathrm{P}_{\mathrm{i}} \min ^{-1} \mathrm{mg}$ protein ${ }^{-1} \pm$ mean standard error.

\begin{tabular}{lccccc}
\hline Dose & $\mathbf{N}$ & $\begin{array}{c}\text { Total } \\
\text { protein }\end{array}$ & $\begin{array}{c}\mathbf{N a}^{+} / \mathbf{K}^{+} \\
\text {-ATPase }\end{array}$ & $\begin{array}{c}\mathbf{M g}^{2+} \\
\text {-ATPase }\end{array}$ & $\begin{array}{c}\mathbf{C a}^{2+} \\
\text {-ATPase }\end{array}$ \\
\hline Control & 12 & 12.26 & $40.74 \pm 1.58$ & $48.72 \pm 0.95$ & $89.46 \pm 2.11$ \\
$\mathbf{L C}_{\mathbf{5 0}} / \mathbf{8}$ & 12 & 9.31 & $30.58 \pm 0.91^{*}$ & $34.37 \pm 0.39^{*}$ & $64.94 \pm 1.12^{*}$ \\
$\mathbf{L C}_{\mathbf{5 0}} / \mathbf{4}$ & 12 & 11.49 & $20.82 \pm 0.62^{*}$ & $27.09 \pm 0.511^{*}$ & $48.01 \pm 0.62^{*}$ \\
$\mathbf{L C}_{\mathbf{5 0}} / \mathbf{2}$ & 9 & 10.77 & $20.17 \pm 1.03^{*}$ & $25.80 \pm 0.60^{*}$ & $45.97 \pm 0.55^{*}$ \\
$\mathbf{L C}_{\mathbf{5 0}}$ & 8 & 11.91 & $11.97 \pm 0.37^{*}$ & $26.07 \pm 0.40^{*}$ & $38.03 \pm 0.29^{*}$ \\
\hline
\end{tabular}

$\mathrm{N}$ : Number of animals that survived after the $96-\mathrm{h}$ acute toxicity test.

${ }^{*}: p<0.05$ showed statistical importance compared with control group

Table 5. Biochemical responses of $96-\mathrm{h}$ Thmx exposure in muscle. Total protein amount expressed as $\mathrm{mg}$ $\mathrm{ml}^{-1}$, and enzyme activities expressed as $\mu \mathrm{mol} \mathrm{P}_{\mathrm{i}} \min ^{-1} \mathrm{mg}$ protein ${ }^{-1} \pm$ mean standard error.

\begin{tabular}{|c|c|c|c|c|c|c|}
\hline Dose & $\mathbf{N}$ & $\begin{array}{c}\text { Total } \\
\text { protein }\end{array}$ & $\begin{array}{c}\mathrm{Na}^{+} / \mathrm{K}^{+} \\
\text {-ATPase }\end{array}$ & $\begin{array}{c}\mathrm{Mg}^{2+} \\
\text {-ATPase }\end{array}$ & & $\begin{array}{c}\mathrm{Ca}^{2+} \\
\text {-ATPase }\end{array}$ \\
\hline Control & 12 & 15.13 & $21.18 \pm 0.91$ & $72.03 \pm 1.32$ & & $93.21 \pm 1.32$ \\
\hline $\mathrm{LC}_{50} / 8$ & 12 & 11.40 & $19.97 \pm 0.44$ & $61.51 \pm 0.98$ & * & $81.48 \pm 1.13^{*}$ \\
\hline $\mathrm{LC}_{50} / 4$ & 12 & 12.19 & $17.55 \pm 0.66^{*}$ & $49.15 \pm 1.04$ & * & $66.70 \pm 0.69$ * \\
\hline $\mathrm{LC}_{50} / 2$ & 9 & 12.02 & $13.18 \pm 0.17^{*}$ & $31.15 \pm 0.06$ & * & $44.33 \pm 0.18$ * \\
\hline $\mathrm{LC}_{50}$ & 8 & 11.37 & $12.32 \pm 0.23$ * & $26.60 \pm 1.25$ & * & $38.92 \pm 1.25^{*}$ \\
\hline
\end{tabular}

$\mathrm{N}$ : Number of animals that survived after the 96 -h acute toxicity test.

${ }^{*}: p<0.05$ showed statistical importance compared with control group

$\mathrm{Na}^{+} \mathrm{K}^{+}$ATPase activity of $O$. niloticus gill tissue increased due to the prolongation of the time. The observed decrease in the activities of $\mathrm{Na}^{+} \mathrm{K}^{+}$ATPase may be due to the change in ionic homeostasis and may also be due to ATP depletion. ${ }^{92}$

In both gill and muscle tissues, $\mathrm{Mg}^{2+} \mathrm{ATPase}$ activity decreased as the applied Thmx concentration increased. The highest reduction was observed in the groups where the highest $\mathrm{Thmx}$ concentration $\left(\mathrm{LC}_{50}\right)$ was applied. $\mathrm{Mg}^{2+}$ ATPase inhibition rates in the gill were $29 \%, 44 \%$, $47 \%, 47 \%$; in muscle, it was $15 \%, 32 \%, 57 \%$ and $63 \%$ compared to control depending on the increase in Thmx concentration. $\mathrm{Mg}^{2+}$ ATPase is an enzyme that ensures the integrity of the cell membrane by transepithelial regulation of $\mathrm{Mg}^{2+}$ ions and is associated with the synthesis of ATP through oxidative phosphorylation in mitochondria. ${ }^{91}$ Inhibition of $\mathrm{Mg}^{2+} \mathrm{ATPase}$ in the present study may have caused a disruption in the transport of ions across the cell membrane and a decrease in ATP production. ${ }^{92,96}$

$\mathrm{Ca}^{2+}$ ATPase was inhibited increasingly as Thmx concentration increased in both gill and muscle tissues. The highest inhibitions in the gill and muscle were seen at the $\mathrm{LC}_{50}$ dose with rates of $57 \%$ and $58 \%$, and the lowest were at the $\mathrm{LC}_{50} / 8$ dose with rates of $27 \%$ and $13 \%$, respectively. All of these inhibition of $\mathrm{Ca}^{2+}$ ATPase activity were statistically significant $(\mathrm{p}<0.05)$. $\mathrm{Ca}^{2+} \mathrm{ATPase}$ is an enzyme that serves to remove calcium $\left(\mathrm{Ca}^{2+}\right)$ from the cell and is vital in regulating the amount of $\mathrm{Ca}^{2+}$ within cells. ${ }^{97}$ Inhibition of $\mathrm{Ca}^{2+}$ ATPase activity in gill and muscle tissues may be associated with the disruption of the osmoregulation mechanism due to the blockage of the active transport system by Thmx. ${ }^{98}$ Additionally, Thmx may have caused inhibition of membrane bound enzymes due to degradation products of lipid peroxidation in the cell membrane by inducing oxidative stress. ${ }^{99}$ This may result in disruption of the active transport mechanism due to altered membrane permeability and impaired $\mathrm{Ca}^{2+}$ ATPase homeostasis. ${ }^{98}$ Similar to our findings, Uçkun and Öz (2020a, 2020b) $)^{51,52}$ observed that ATPase activities $\left(\mathrm{Na}^{+} \mathrm{K}^{+}\right.$ATPase, $\mathrm{Mg}^{2+}$ ATPase, $\mathrm{Ca}^{2+}$ ATPase) in gill and muscle tissues decreased significantly in a dose-dependent manner in two separate studies in which A. leptodactylus applied the fungicides penconazole and azoxystrobin for 96 hours. In our study, the ATPase inhibition rates in the gill were found to be higher than those in the muscle. This decrease is thought to be the result of impairment of ion balance and gill permeability, since it is the first tissue in contact with the pesticide in the aquatic environment. In fish, various toxic substances and ions enter the body by absorption and adsorption by the gill surface, followed by diffusion. Interaction with the membrane may impair the osmotic and ionic regulation of gill tissue by affecting membrane permeability. ${ }^{93}$ The reason that responses to biomarkers vary according to the organ is related to the defense capacities of the organs as well as their anatomical location that determines the path and distribution of xenobiotic exposure. ${ }^{92}$ 
When evaluating the responses of biomarkers, we used IBR analysis to allow combining all parameters into one general stress index (Figure 1). IBR analysis is a useful method that provides a brief information in comparing multiple biomarkers. ${ }^{100}$ The IBR index expressing the toxicity caused by Thmx in the hepatopancreas was determined to be the highest at the $\mathrm{LC}_{50}$ dose. At the $\mathrm{LC}_{50} / 2$ and $\mathrm{LC}_{50} / 4$ doses, the IBR index was found to be close to each other and lower than the $\mathrm{LC}_{50}$ dose. Compared to other doses, the lowest IBR index was determined at the $\mathrm{LC}_{50} / 8$ dose. As can be seen, although hepatopancreas IBR index rised with increasing Thmx dose, it was suppressed compared to control. This may be because the hepatopancreas plays a role in detoxification. In gill and muscle tissues, IBR index was inhibited compared to the control due to increasing Thmx dose. The IBR index was completely suppressed at the $\mathrm{LC}_{50}$ dose in both tissues because ATPase inhibitions were highest at this dose. The findings of our study are in line with various studies using the IBR index in the assessment of the effects of environmental pollutants on macroinvertebrate ${ }^{40}$, mussel ${ }^{101}$ and fish. ${ }^{102,103}$

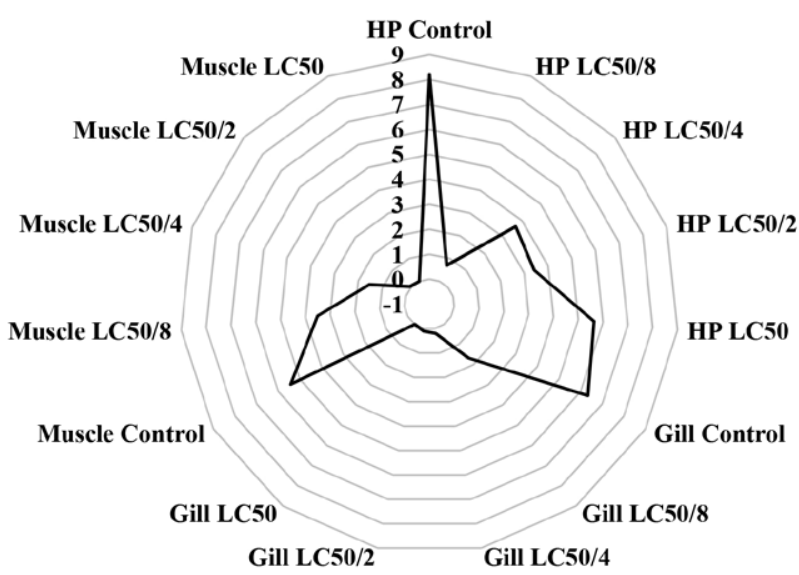

Figure 1. IBR analysis of biomarkers in the hepatopancreas, gill, and muscle.

\section{Conclussion}

Information on the potential ecotoxicological effects of Thmx with respect to freshwater crustaceans is still limited. In this context, our study has made an important contribution to the literature on the toxic effects of Thmx on non-target organisms. Our study shows that Thmx has significant toxic effects on A. leptodactylus even at low concentrations. Therefore we can say that $A$. leptodactylus living in fresh waters close to the agricultural areas where Thmx is used may be under threat. Since almost all of the biomarkers used in our study respond to Thmx administration, we would like to state that these markers are useful in reflecting the acute toxicity of Thmx in crayfish.

\section{Compliance with Ethical Standards}

All applicable international, national, and/or institutional guidelines for the care and use of animals were followed. All procedures performed in studies involving animals were in accordance with the ethical standards of the institution or practice at which the studies were conducted.

\section{Conflict of Interest}

The authors declare that they have no conflict of interest.

\section{References}

1. D. Pietrzak, J. Kania, E. Kmiecik, G. Malina, Chemosphere. 2020, 126981. DOI:10.1016/j.chemosphere.2020.126981.

2. P. Maienfisch, M, Angst, F. Brandl, W. Fischer, D. Hofer, H. Kayser, W. Kobel, A. Rindlisbacher, R. Senn, A. Steinemann, H. Widmer, Pest Manag Sci. 2001a, 57, 906-913. DOI:10.1002/ps.365.

3. P. Maienfisch, H. Huerlimann, A. Rindlisbacher, L. Gsell, H. Dettwiler, J. Haettenschwiler, E. Sieger, M. Walti, Pest Manag Sci, 2001b, 57, 165-176. DOI:10.1002/1526-4998(200102) 57:2<165::AID-PS289>3.0.CO;2-G.

4. C. I. Rumbos, A. C. Dutton, C. G. Athanassiou, J Stored Prod Res. 2018, 75, 56-63. DOI:10.1016/j.jspr.2017.10.004.

5. X. P. Zhao, C. X. Wu, Y. Wang, T. Cang, L. Chen, R. Yu, Q. Wang, J Econ Entomol. 2012, 105, 92-101. DOI:10.1603/EC11259.

6. J. E. Casida, K.A. Durkin. Chem Biol Interact. 2013, 203, 221225. DOI:10.1016/j.cbi.2012.08.002.

7. M. C. Finnegan, L. R. Baxter, J. D. Maul, M. L. Hanson, Environ Toxicol Chem. 2017, 36, 2838-2848.

DOI:10.1002/etc.3846.

8. P. Jeschke, R. Nauen, M, Schindler, A. Elbert, J Agric Food Chem. 2011, 59, 2897-2908. DOI:10.1021/jf101303g.

9. W. J. Zhang, W. Liu, J. Zhang, H. Zhao, Y. Zhang, X. Quan, Y. Jin, J Environ Sci. 2012, 24, 2019-2027. DOI:10.1016/S1001-0742(11)61030-9.

10. C. A. Morrissey, P. Mineau, J. H. Devries, F. Sanchez-Bayo, M. Liess, M. C. Cavallaro, K. Liber, Environ Int. 2015, 74, 291-303. DOI:10.1016/j.envint.2014.10.024.

11. A. R. Main, J. V. Headley, K. M. Peru, N. L. Michel, A. J. Cessna, C. A. Morrissey, PLoS One 2014, 9, 92821.

DOI:10.1371/journal.pone.0092821.

12. L. W. Pisa, V. Amaral-Rogers, L. P. Belzunces et al., Environ Sci Pollut Res Int. 2015, 22, 68-102.

DOI:10.1007/s11356-014-3471-x.

13. Defra, 2014. https://secure.fera.defra.gov.uk/pusstats. Accessed 07 Feb 2014.

14. G. Köksal, Astacus leptodactylus in Europe. Freshwater Crayfish: Biology, Management and Exploitation, Croom Helm, London. 1988, 365-400.

15. P. Nyström, Biology of freshwater crayfish. Blackwell Science, 
Oxford, UK. 2002, 192-235.

16. S. P. Zhang, H. Jin, Y. Feng, L. Zhang, J. Lu, Acta Hydrobiol Sinica. 2003, 27, 496-501

17. P. Alcorlo, M. Otero, M. Crehuet, A. Baltanás, C. Montes, Sci Total Environ. 2006, 366, 380-390.

DOI:10.1016/j.scitotenv.2006.02.023.

18. E. Tunca, S. Atasagun, A. Y. Sayg1, Ecology. 2012, 21, 68-76. DOI:10.5053/ekoloji.2012.838.

19. G. W. Winston, R. T. Di Giulio, Aquat Toxicol. 1991, 19, 137161. DOI:10.1016/0166-445X(91)90033-6.

20. R. T. Di Giulio, J. N. Meyer, Reactive oxygen species and oxidative stress. In: Di Giulio RT, Hinton DE, editors. The Toxicology of Fishes. Boca Raton: CRC Press, Taylor and Francis Group. 2008, 273-324.

21. ASTM E729-96. Standard Guide for Conducting Acute Toxicity Tests on Test Materials with Fishes, Macroinvertebrates, and Amphibians. 2014.

22. R. L. Anderson. Environ Entomol. 1982, 11, 1251-1257. DOI:10.1093/ee/11.6.1251.

23. B. Leksrisawat, A. S. Cooper, A. B. Gilberts, R. L. Cooper, J Vis Exp. 2010, 45, 2323. DOI:10.3791/2323.

24. M. M. Bradford, Anal Biochem. 1976, 72, 248-254. DOI:10.1016/0003-2697(76)90527-3.

25. W. H. Habig, M. J. Pabst, W. B. Jakoby, J Biol Chem. 1974, 249, 7130-7139. DOI:10.1016/S0021-9258(19)42083-8.

26. E. Cribb, J. S. Leeder, S.P. Spielberg, Anal Biochem. 1989, 183, 195-196. DOI:10.1016/0003-2697(89)90188-7.

27. P. Santhoshkumar, T. Shivanandappa, Chem-Biol Interact. 1999, 119, 277-282. DOI:10.1016/S0009-2797(99)00037-X.

28. J. G. Bell, C. B. Cowey, J. W. Adron, A. M. Shanks, Br J Nutr. 1985, 53, 149-157. DOI:10.1079/bjn19850019.

29. Y. Sun, L. W. Oberley, Y. Li, Clin Chem. 1988, 34, 497-500. DOI:10.1093/clinchem/34.3.497

30. M. S. Moron, J. W. Depierre, B. Mannervik, Biochim Biophys Acta. 1979, 582, 67-78. DOI:10.1016/0304-4165(79)90289-7.

31. Z. A. Placer, L. L. Cushman, B. C. Johnson, Anal Biochem. 1966, 16, 359-364. DOI:10.1016/0003-2697(66)90167-9.

32. G. L. Ellman, D. C. Andres, Biochem Pharmacol. 1961, 7, 88-95. DOI:10.1016/0006-2952(61)90145-9.

33. M. Ozmen, S, E, Dominguez, A, Fairbrother, Bull Environ Contam Toxicol. 1998, 60, 194-201.

DOI:10.1007/s001289900610.

34. G. Atl1, M. Canl, Ecotoxicology. 2011, 20, 1861-1869. DOI:10.1007/s10646-011-0724-z.

35. Atkinson, A. O. Gatemby, A. G. Lowe, Biochim. Biophys. Acta. 1973, 320, 195-204. DOI:10.1016/0304-4165(73)90178-5.

36. M. A. Arzate-Cárdenas, F. Martínez-Jerónimo, Environmental Toxicology and Pharmacology, 2012, 34, 106-116. DOI: https://dx.doi.org/10.1016/j.etap.2012.03.003.

37. V. Korkmaz, A. Güngördü, M. Ozmen, Ecotoxicol Environ Saf. 2018, 160, 265-272. DOI:10.1016/j.ecoenv.2018.05.055.

38. G. C. Barbee, M. J. Stout, Pest Manag Sci. 2009, 65, 12501256. DOI:10.1002/ps.1817.

39. E. M. Maloney, C. A. Morrissey, J. V. Headley, K.M. Peru, K. Liber, Ecotoxicol Environ Safe. 2018, 156, 354-365.

DOI:10.1016/j.ecoenv.2018.03.003.
40. Ö. Demirci, K. Güven, D. Asma, S. Öğüt, P. Uğurlu, Ecotoxicol Environ Safe. 2018, 147, 749-758.

DOI:10.1016/j.ecoenv.2017.09.038.

41. P. Uğurlu, E. Ünlü, E. I. Satar, Ecotox Environ Safe. 2015, 39, 720-726. DOI:10.1016/j.etap.2015.01.013.

42. S. S. Mahnaz, P. Sadegh, Oceanogr Fish Open Access J. 2018, 7 , 555-722. DOI:10.19080/OFOAJ.2018.07.555722.

43. Y. Han, T. Liu, J. Wang. C. Zhang, L. Zhu, Pestic Biochem Phys. 2016, 133, 13-19. DOI:10.1016/j.pestbp.2016.03.011.

44. V. V. Husak, N. M. Mosiichuk, J. M. Storey, K. B. Storey, V. I. Lushchak, Comp Biochem Phys C. 2017, 193, 1-8.

DOI:10.1016/j.cbpc.2016.12.003.

45. L. Liu, B. Zhu, G. X. Wang. Environ Sci Pollut Res Int. 2015, 22, 7766-7775. DOI:10.1007/s11356-015-4121-7.

46. S. Mukanganyama, C. Figueroa, J. Hasler, H. Niemeyer, J Insect Physiol. 2003, 49, 223-229.

DOI:10.1016/s0022-1910(02)00269-x.

47. C. Wang, G. Lu, J. Cui, P. Wang, Environ Toxicol Pharmacol. 2009, 28, 414-419. DOI:10.1016/j.etap.2009.07.005.

48. Sayeed, S. Parvez, S. Pandey, B. Bin-Hafeez, R. Haque, S. Raisuddin, Ecotoxicol Environ Safe. 2003, 56, 295-301.

DOI:10.1016/s0147-6513(03)00009-5.

49. E. O. Oruç, Pestic Biochem Physiol. 2010, 96, 160-166. DOI:10.1016/j.pestbp.2009.11.005.

50. S. Moreira, M. Moreira-Santos, J. Rendón-von Osten, E. M. Silva, R. Ribeiro, L. Guilhermino, A.M.V.N. Soares, Ecotoxicol Environ Safe. 2010, 73, 893-899.

DOI:10.1016/j.ecoenv.2010.04.007.

51. A. Uçkun, Ö. B. Öz, Environ Sci Pollut Res. 2020a, 27, 3562635637. DOI:10.1007/s11356-020-09595.

52. A. Uçkun, Ö. B. Öz, Drug Chem Toxicol. 2020b. DOI:10.1080/01480545.2020.1774604.

53. R. Van der Oost, J. Beyer, N. P. Vermeulen, Environ Toxicol Phar. 2003, 13, 57-149.

DOI:10.1016/S1382-6689(02)00126-6.

54. T. Szkudelski, Physiol Res. 2001, 50, 537-546. DOI:10.1177/0148333101050003101

55. N. Lenfant, T. Hotelier, E. Velluet, Y. Bourne, P. Marchot, A. Chatonnet, Nucleic Acids Res. 2013, 41, D423-9.

DOI:10.1093/nar/gks1154.

56. J. Lian, R. Nelson, R. Lehner. Protein Cell. 2018, 9, 178-195. DOI:10.1007/s13238-017-0437-z.

57. T. Satoh, M. Hosokawa, Chem-Biol Interact. 2006, 162, 195211. DOI:10.1016/B978-012088523-7/50017-X.

58. M. K. Ross, J. A. Crow, J Biochem Mol Toxicol. 2007, 21,18796. DOI:10:1002/jbt.20178.

59. H. Ozaki, K. Sugihara, Y. Watanabe, K. Moriguchi, N. Uramaru, T. Sone, S. Ohta, S. Kitamura, Food Chem Toxicol. 2017, 100, 217-224. DOI:10.1016/j.fct.2016.12.019.

60. D. L. Denton, C. E. Wheelock, S. Murray, L. A. Deanovic, B. D. Hammock, D. E. Hinton, Environ Toxicol Chem. 2003, 22, 336-341. DOI:10.1002/etc.5620220214.

61. C. E. Wheelock, K. J. Eder, I. Werner, H. Huang, Aquat Toxicol. 2005, 74, 172-192. DOI:10.1016/j.aquatox.2005.05.009.

62. Moreno, S. Pichardo, L. Góomez-Amores, A. Mate, C. M. Vazquez, A. M. Cameán, Toxicon. 2005, 45, 395-402. 
DOI:10.1016/j.toxicon.2004.11.001.

63. K. S. El-Gendy, N. M. Aly, F. H. Mahmoud, A. Kenawy, A. K. H. El-Sebae, Food Chem Toxicol. 2010, 48, 215-221.

DOI:10.1016/j.fct.2009.10.003.

64. M. L. Ballesteros, D. A. Wunderlin, M. A. Bistoni, Ecotoxicol Environ Saf. 2009, 72, 199-205.

DOI:10.1016/j.ecoenv.2008.01.008.

65. S. M. Yonar, M. Ş. Ural, S. Silici, M. E. Yonar, Ecotoxicol Environ Safe. 2014, 102, 202-209.

DOI:10.1016/j.ecoenv.2014.01.007.

66. J. Blahova, L. Plhalova, M. Hostovsky, L. Divišová, R. Dobšíková, I. Mikulíková, S. Šte pánová, Z. Svobodová, Food Chem Toxicol. 2013, 61, 82-85. DOI:10.1016/j.fct.2013.02.041.

67. H. Kappus, Lipid peroxidation: Mechanisms, analysis, enzymology and biological relevance. In: Oxidative Stress, London: Academic Press. 1985, 273-310.

DOI:10.1016/B978-0-12-642760-8.50016-8

68. A. Doyotte, C. Cossu, M. C. Jacquin, M. Babut, P. Vasseur, Aquat Toxicol. 1997, 39, 93-110.

69. E. Ö. Oruç, D. Usta, Environ Toxicol Pharmacol. 2007, 23, 48-55. DOI:10.1016/j.etap.2006.06.005.

70. İ. Celik, H. Suzek, Ecotoxicol Environ Saf. 2009, 72, 905-908. DOI:10.1016/j.ecoenv.2008.04.007.

71. L. Zhu, X. Dong, H. Xie, J. Wang, J. Wang, J. Su, C. Yu, Environ Toxicol. 2011, 26, 480-488. DOI:10.1002/tox.20575.

72. L. Gate, J. Paul, G. N. Ba, K. D. Tew, H. Tapiero, Biomed Pharmacother. 1999, 53, 169-180.

DOI:10.1016/S0753-3322(99)80086-9.

73. C. C. C. Cheung, G. J. Zheng, A. M. Y. Li, B. J. Richardson, P. K. Lam, Aquat Toxicol. 2001, 52, 189-203.

DOI:10.1016/s0166-445x(00)00145-4.

74. Venturino, O. L. Anguiano, L. Gauna, C. Cocca, R. M. Bergoc, A. M. P. D’Angelo, Comp Biochem Physiol C Toxicol Pharmacol. 2001, 130, 191-198.

DOI:10.1016/S1532-0456(01)00241-1.

75. A. Ferrari, A. Venturino, A. M. P. de D’Angelo, Pestic Biochem Physiol. 2007, 88, 134-142.

DOI:10.1016/j.pestbp.2006.10.005.

76. O. Serdar, N. C. Yildirim, S. Tatar, N. Yildirim, A. Ogedey, Environ Sci Pollut Res. 2018, 1-7.

DOI:10.1007/s11356-018-1491-7.

77. N. C. Yildirim, M. Tanyol, N. Yildirim, O. Serdar, S. Tatar, Ecotoxicol Environ Safe. 2018, 156, 41-47.

DOI:10.1016/j.ecoenv.2018.02.059.

78. O. Serdar, Environ Sci Pollut Res. 2019, 26, 1905-1914. DOI:10.1007/s11356-019-04629-w.

79. E. O. Oruç, Y. Sevgiler, N. Uner, Comp Biochem Physiol C. 2004, 137, 43-51. DOI:10.1016/j.cca.2003.11.006.

80. D. A. Monteiro, J. A. Almeida, F. T. Rantin, A. L. Kalinin, Comp Biochem Physiol Part C. 2006, 143, 141-149.

DOI:10.1016/j.cbpc.2006.01.004.

81. F. Regoli, M. Nigro, E. Orlando. Aquat Toxicol. 1998, 40, 375392. DOI:10.1016/S0166-445X(97)00059-3.

82. J. Wang, W. Ge, S. Yan, L. Zhu, A. Chen, J. Wang, J Agric Food Chem. 2015, 63, 1856-1862. DOI:10.1021/jf504895h.

83. S. Shukla, R. C. Jhamtani, M. S. Dahiya, R. Agarwal, Toxicol
Rep. 2017, 4, 240-244.

DOI:10.1016/j.toxrep.2017.05.002.

84. M. Kaur, R. Jindal, MOJ Biol Med. 2017, 1, 103-112. DOI:10.15406/mojbm.2017.01.00021

85. M. B. Colovic, D. Z. Krsti, T. D. Lazarevic-Pasti, A. M. Bondzic, V. M. Vasi, Curr. Neuropharmacol. 2013, 11, 315-335. DOI:10.2174/1570159X11311030006.

86. S. Saraiva, R. A. Sarmento, A. C. M. Rodrigues, D. Campos, G. Fedorovac, V. Žlábek, C. Gravato. J. L. T. Pestana, A. M. V. M. Soares Ecotoxicol Environ Safe. 2017, 137, 240-246. DOI:10.1016/j.ecoenv.2016.12.009.

87. F. Dondero, A. Negri, L. Boatti, F. Marsano, F. Mignone, A. Viarengo, 2010. Sci Total Environ. 2010, 408, 3775-3786. DOI:10.1016/j.scitotenv.2010.03.040.

88. H. M. V. S. Azevedo-Pereira, M. F. L. Lemos, A. M. V. M. Soares, 2011. Water Air Soil Pollut. 2011, 219, 215-224. DOI:10.1007/s11270-010-0700-x.

89. M. Mörtl, A. Vehovszky, S. Klátyik, E. Takács, J. Győri, A. Székács, Int J Environ Res Public Health. 2020, 17, 2006. DOI:10.3390/ijerph17062006.

90. K. Takao, Physiol Rev. 1985, 65, 467. DOI:10.1152/physrev.1985.65.2.467.

91. T. Clausen, Physiol Rev. 2003, 83, 1269-1324. DOI:10.1152/physrev.00011.2003.

92. G. Begum, Fish Physiol Biochem. 2011, 37, 61-69. DOI:10.1007/s10695-010-9417-4.

93. M. David, J. Sangeetha, E. R. Harish, J. Shrinivas, V. R. Naik, Int J Pure Appl Zool. 2014, 2, 175-181.

94. G. Balaji, M. Nachiyappan, R. Venugopal. World J Zool. 2015, 10, 168-174. DOI:10.5829/idosi.wjz.2015.10.3.9581.

95. Ö. Temiz, H. Y. Çoğun, F. Kargın, Fresen Environ Bull. 2018, 27, 5027-5032.

96. T. A. Kumosani, JKAU Sci. 2005, 17, 143-152. DOI:10.4197/Sci.17-1.15.

97. P. Gmaj, H. Murer, Physiol Rev. 1986, 66, 36-70. DOI:10.1152/physrev.1986.66.1.36.

98. N. P. Okolie, K. Audu, J Biomed Scien. 2004, 3, 37-44. DOI:10.4314/jmbr.v3i1.10654.

99. S. Daya, R. B. Walker, S. Anoopkumar-Dukie, Metab Brain Dis. 2000, 15, 203-210. DOI:10.1007/BF02674529.

100. Venturino, E. Rosenbaum, A. Caballero, O. Anguiano, Biomarkers. 2003, 8, 167-186. DOI:10.1080/1354700031000120116.

101. S. J. Brooks, C. Harman, M. T. Hultman, J. A. Berge, Science and Total Environment, 2015, 524, 104-114. DOI:10.1016/j.scitotenv.2015.03.135.

102. Z. H. Li, J. Velisek, V. Zlabek, R. Grabic, J. Machova, J. Kolarova, P. Li, T. Randak, J. Hazard. Mater. 2011, 185, 870-880. DOI:10. 1016/j.jhazmat.2010.09.102.

103. T. Suman, S. R. R. Rasajree, R. Kirubagaran, Ecotoxicol. Environ. Saf. 2015, 113, 23-30.

DOI:10.1016/j.ecoenv.2014.11. 015. 


\section{Povzetek}

Tiametoksam (Thmx) je globalno razširjen neonikotinoidni pesticid, ki onesnažuje sladkovodne ekosisteme in katerega ostanke so zaznali v ribiških proizvodih. Astacus leptodactylus je priljubljen sladkovodni rak, ki ga gojijo in izvažajo v mnogih državah. V okviru raziskave smo preučevali akutne toksične učinke Thmx na A. leptodactylus $\mathrm{z}$ uporabo različnih biomarkerjev (acetilholinesteraza, karboksilesteraza, glutation S-transferaza, glutation, superoksidna dismutaza, glutation peroksidaza, glutation reduktaza in adenozintrifosfataze). 96-urna vrednost $\mathrm{LC}_{50}$ Thmx je bila izračunana kot $8.95 \mathrm{mg}$ aktivne učinkovine $\mathrm{L}^{-1}$. Ko se je odmerek Thx povečeval, je oksidativni stres povzročil inhibicijo/ aktivacijo antioksidativnih encimov, medtem ko so bile aktivnosti acetilholinesteraze, karboksilesteraze in adenozintrifosfataz inhibirane. Posledično lahko rečemo, da Thmx izkazuje močno toksične učinke na rake, zato so ti na območjih, kjer se ta pesticid uporablja, ogroženi. 